\section{Kastamonu Eğitim Dergisi Kastamonu Education Journal}

Mayıs 2019 Cilt:27 Sayı:3

kefdergi.kastamonu.edu.tr
Başvuru Tarihi/Received: 12.06 .2018

Kabul Tarihi/Accepted: 10.07 .2018 DOI: $10.24106 /$ kefdergi.3149

\title{
Öğrenci Hemşirelerin Öğrenim Gördükleri Fakültedeki Örtük Programa İlişkin Görüşlerinin İncelenmesi ${ }^{1}$
}

\section{Investigation of Nursing Students' Views of Hidden Curriculum in Their Own Faculties}

\section{Öz}

\author{
Fatma ORGUN², Nilay ÖZKÜTÜK³ ${ }^{3}$ Berna AKÇAKOCA ${ }^{4}$
}

Bir hemşirelik fakültesinde öğrenim gören öğrencilerin fakültelerindeki örtük program ile ilgili görüşlerini incelenmek, farkındalık yaratmak amacı ile yapılan tanımlatıcı tipteki çalışma 304 öğrenci ile yürütülmüştür. Araştırma verileri sosyo-demografik veri formu ve "Örtük Program Ölçeği”" ile toplanmıştır. Verilerin çözümlenmesinde, SPSS 20.0 programı kullanılarak, yüzde dağıımları, t-testi, varyans ve korelasyon analizleri yapılmıştır. Araştırma sonuçlarına göre, Cronbach's $\alpha$ katsayısı ölçeğin toplamında .90 olarak bulunmuştur. Çalışmanın yapıldığı fakültede örtük program algısının orta düzeyde olduğu saptanmış ve eğitim yapılan kurumu tanıma düzeyi, öğrenci algısı ve olgunluğu arttıkça örtük program uygulandığı algısı artmıştır.

Anahtar Kelimeler: hemşirelik eğitimi, örtük program, öğrenci hemşire

\section{Abstract}

A descriptive study was conducted with 304 students in order to examine the opinions of the students in a nursing faculty, and raise awareness about the hidden curriculum in their faculty. The research data was collected using socio-demographic data form and "Hidden Curriculum Scale". Data analysis was done percent distribution, t-test, variance and correlation analyzes and were computed using SPSS 20.0 program. According to research results, Cronbach's a coefficient was found .90 for the total of the scale. It was determined that the hidden curriculum perception was moderate in the faculty. Perception of a hidden curriculum being implemented increased correspondingly as the students' level of recognition of the institution being educated, and student perception and maturity increased.

Keywords: nursing education, hidden curriculum, nursing student

1. Bu çalışma daha önce IVth İnternational Eurasian Educational Research Congress (EJER 2017)' de sözel bildiri olarak sunulmuştur

2. Ege üniversitesi, Hemşirelik Fakültesi, İzmir, Türkiye.; https://orcid.org/0000-0002-2351-7227

3. Ege üniversitesi, Hemşirelik Fakültesi, İzmir, Türkiye.; https://orcid.org/0000-0003-1405-4600

4. Ege üniversitesi, Hemşirelik Fakültesi, İzmir, Türkiye.; https://orcid.org/0000-0001-8493-2742

Atıf / Citation: Orgun, F., Özkütük, N., \& Akçakoca, B. (2019). Öğrenci hemşirelerin öğrenim gördükleri fakültedeki örtük programa ilişkin görüşlerinin incelenmesi. Kastamonu Education Journal, 27(3), 1337-1345. doi:10.24106/kefdergi.3149 


\section{Extended Summary}

Aim: All institutions providing education and schooling are implementing an official written and planned education program. However, students are not only influenced by this formal and planned program, but by another unplanned and non-written program. The experts who support this idea emphasize that there are two types of programs in every school. The first of these programs is formal, written and clearly specified official program; and the other is informal, a "hidden curriculum" that is unspecified and unstructured.

In general terms informal, an "hidden curriculum can be defined as the knowledge, opinions, perceptions, practices and values that students acquire outside the aims and activities stated in the official program implementations; and can give strong messages about political socialization, the infusion of values, the maintenance of traditional class structure, authority, control, obedience and hierarchy.

An unwritten system that guides these practices is hidden under all implementations in the university, and this system is also executed with an informal, a hidden curriculum. As in all other educational-schooling programs, nursing education was observed to be exceedingly influenced by the informal, a hidden curriculum. It has been determined that faculty, academicians and practice areas convey their views, beliefs, values, and expectations explicitly or implicitly to their students during the teaching-learning processes. As a matter of fact, it is a known fact that there are difference between the students graduating from the same department. The standards of the university, academic staff, students' social class origins and academic achievement level, and social and academic life in the university; briefly the universities informal, a hidden curriculum is the reason for this difference.

There is no adequate research in the field of nursing on the informal, a hidden curriculum known to be as effective as the official program. In this context, this study was carried out with a purpose of examining opinions of students in a nursing faculty about the hidden curriculum in their school, creating awareness about the subject, and contributing to the recognition and evaluation of their own hidden curriculum of an educational institution.

Method: The study is a descriptive type of study conducted at a nursing faculty. The data required for the research were collected from 304 1st, 2nd, 3rd and 4th grade nursing students who accepted to participate the investigation that involves completing a questionnaire consisting of two parts; "Introductory Information Form" and "Hidden Curriculum Scale".

In the first part of the data collection tool, 19 questions including socio-demographic characteristics such as gender, age, and class were used to identify the sample. The second part is the "Hidden Curriculum Scale". The scale consists of 21 items; "Content", "Learning-Teaching Process" and "Evaluation" makes 3 sub dimensions. As scores given to scale items increase, hidden curriculum perception increases.

SPSS 20.0 program was used to compute percent distributions, t-test, variance, and correlation analysis; with a significance level of .05.

Result and discussion: This study, which was conducted to determine the hidden curriculum perceptions to the institution they are studying, the hidden curriculum perception of the student nurses to their faculty is found to be moderate. Being a man, choosing the occupation by chance, being over 24 years old, disliking the profession; and decreased satisfaction from education program, school management, teaching staff, administrative staff, and clinical nurses was found to increase hidden curriculum perception.

According to research results, it is a fact that hidden curriculum affects the students in many issues from loving their profession to satisfaction in their occupation. The hidden curriculum should be seen as an advantage, incentive, and orientation tool in the process of acquiring values in nursing education, in which the overall goal of higher education is attaining a modern human profile with advanced values system and to nurture professional nurses embarrassing lifelong learning. It should also be made into planned activities as in the official program.

In consequence of the research, the total scores of some scale items $(6,17,21,1)$ were found to be quite high. By reviewing these materials, which subject of the hidden curriculum perception is more important could be determined; the information may be shared with faculty management and staff, and necessary measures can be taken in that direction or ideas can be generated for necessary innovations as well. It is suggested that this subject, which is known to be at least as effective as the official program and also very important for nursing education, should be supported with further studies. 


\section{Giriş}

Eğitim öğretim faaliyetleri planlı ve amaçlı bir şekilde gerçekleşmektedir. Bu nedenle eğitim-öğretim veren tüm kurumlar resmi olarak hazırlanmış yazılı ve planlı formal bir eğitim programı uygulamaktadır. Ancak öğrencilerin bu resmi ve planlı programın yanında planlanmamış ve yazııı olmayan başka bir programdan daha etkilendikleri bilinmektedir. Bu düşünceyi destekleyen yazarlar her okulda bu iki tür programın yer aldığını belirtmektedir. Bu programlardan birincisi, formal; yazılı ve açıkça belirli olan resmi program, diğeri ise informal olarak ortaya çıkan; açıkça belirtilmemiş ve yazilı olmayan "örtük program" dır (Yüksel 2002a, Flinders ve Thornton 2004, Ornstein ve Hunkins 2009, Allan, Smith ve O’Driscoll 2010, Senemoğlu 2013, Başar ve ark. 2014, Demirel 2015, Wilkson 2016).

Formal (resmi) program kavramı iyi bilinmesine rağmen örtük program geri planda kalmış bir kavram olarak göze çarpmaktadır. Örtük program tanımını ilk olarak sosyolog Philip Jackson'ın (1968) kullandığı kabul görmektedir (Yüksel, 2002b). Jackson örtük programı; öğrencilerin toplumla uyumlu olması için sadık olma, itaat etme gibi olguları öğretim aracı olarak tanımlanmaktadır. Ayrıca bu tanım iş, otorite, sosyal kurallarla ilgili okulda verilen mesajları da içermektedir. (Flinders ve Thornton 200, Ornstein ve Hunkins 2009, Allan ve ark. 2010). Örtük program kavramına karşılık olarak kaynaklarda "açıkça belirtilmemiş program", "gizli program", "okullaşmanın akademik olmayan çıktıları" ve "okullaşmanın insana yaptkları" ifadeleri de kullanılmaktadır. (Vallanca1983, Giroux 2001; Akt: Bolat 2014). Genel anlamda bakıldığında ise örtük program; öğrencilerin resmi program uygulamalarında belirtilen amaç ve faaliyetlerin yanında kazandıkları bilgi, görüş, algı, uygulama ve değerler şeklinde tanımlanabilir (Skelton 1997, Brammer 2006, Allan ve ark. 2010). Bir diğer deyişle örtük program, eğitim kurumunun öngörmediği ancak öğrencinin kazandığı davranış değişiklikleridir şeklinde de tanımlanabilir (Bacanlı 2006). Bu bağlamda örtük program, değerlerin aşılanması, siyasal toplumsallaşma, geleneksel sınıf yapısının sürdürülmesi, otorite, kontrol, itaat ve hiyerarşi ile ilgili güçlü mesajlar vermektedir (Takala ve Hawk 2001).

Üniversitelerin toplumdaki yeri ve mezun öğrenci profilleri arasında farklılıklar olduğu açıkça bilinen durumdur. Araştırmacılar bu farkların sebebini; üniversitenin standartları, akademik kadrosu, öğrencilerin geldikleri sosyal sınıf ve akademik başarı düzeyleri, üniversitenin sosyal ve akademik yaşamı gibi kısacası üniversitenin 'örtük programı'olarak açıklamışlardır (Yüksel 2002b). Üniversite düzeyinde bakıldığında; adanmışlık, güçlü bir sorumluluk duygusu ve yüksek ahlaki değere sahip olmayı gerektiren hemşirelik mesleği de eğitimi boyunca, diğer tüm eğitim-öğretim programlarında olduğu gibi örtük programdan fazlasıyla etkilenmektedir. Hemşirelik, sadece bir kişisel eğitim ve gelişim süreci değil aynı zamanda, kişiler arası ilişkiler ve kültürel değerlerle şekillenir. Bu bağlamda örtük programın, öğrencinin mesleki kimlik oluşumuna büyük katkı sağladığı bilinmektedir (Tresolini 1994).

Yapılan araştırmalarda eğitim kurumunun, öğretim elemanlarının ve uygulama alanlarının öğretme-öğrenme süreçlerinde görüşlerini, inançlarını, değer ve beklentilerini açık ve ya örtük bir şekilde öğrencilerine ilettiği görülmüştür (Yüksel 2002a, Brammer 2006, Allan ve ark. 2010, Jafree ve Ark. 2015). Hemşirelik öğrencilerinin eğitim-öğretimleri sırasında fakülteden, öğretim elemanlarından, klinik eğitime destek veren hemşirelerden, yönetici hemşirelerden ve rol model alınan öğrenci hemşirelerden; profesyonel davranışlarda, mesleki uygulamalarda, eğitim ve uygulama sırasındaki olumlu ve olumsuz tutumlarında, mesleği algılama biçimlerinde ve mesleki sosyalleşmelerinde fazlasıyla etkilendiği görülmektedir. Bu etkilerin her zaman olumlu yönde olduğunu söylemek zordur. Birçok öğrenci eğitim öğretim süreçleri boyunca örtük program çerçevesinde kalan etkilerden dolayı olumsuz deneyimler de edinebilmektedir (Skelton 1997, Brammer 2006, Jafree 2015, Wilkson 2016). Bu yüzden bireylerin bir bütün olarak yetiştirilmesinde, öğrenme ve öğretmenin gerçekleştiği eğitim süreci bir bütün olarak ele alınmalı ve incelenmelidir.

Türkiye'de hemşirelik eğitimi verilen kurumlarda bu konuyla ilgili yeterli çalışma bulunmamaktadır. Bu araştrrma, bir hemşirelik fakültesinde öğrenim görmekte olan öğrencilerin fakültelerindeki örtük program ile ilgili görüşlerini incelenmek ve farkındalık yaratmak amacı ile yapıımıştır.

Araştırmanın yükseköğretimde hemşirelik eğitiminin niteliğini arttırmaya yönelik yapılacak çalışmalara, fakültenin ve öğretim elemanlarının kendi örtük programlarını tanıyıp değerlendirmelerine ve gerekli değişimlerin yapılabilmesi için geçerli bir kaynak oluşturması açısından katkı sağlayacağı düşünülmektedir.

\section{Gereç ve Yöntem}

Araştırma, hemşirelik bölümü öğrencilerinin fakültelerindeki örtük program hakkında görüşlerini incelemek amacı ile yapılan tanımlayıcı tipte bir çalışmadır. Örneklemini, bir hemşirelik fakültesinde öğrenim gören 1, 2, 3 ve 4. sınıf hemşirelik öğrencileri oluşturmuştur. Örneklem sayısı, evreni bilinen örneklem seçimi formülünden yararlanılarak hesaplanmış ve araştırmaya toplamda 304 kişi dahil edilmiştir. 
Araştırma için gerekli olan veriler "Tanıtıcı Bilgi Formu" ve "Örtük Program Ölçeği" olmak üzere iki bölümden oluşan bir anket formu ile toplanmıştır.

Tanıtıcı Bilgi Formu için ilk bölümünde örneklemi tanımayı sağlayan ve fakültedeki örtük programa ilişkin görüşlerini elde etmeye yarayan maddeler yazılmıştır. Bu kapsamda cinsiyet, yaş, sınıf gibi sosyo-demografik özellikleri içeren toplam 19 soru yer almıştir.

Akbulut ve Aslan (2016) tarafindan geliştirilen 'Örtük Program Ölçeği', 21 maddeden ve "içerik”, "Öğrenme-Öğretim Süreci" ve "Değerlendirme" olmak üzere üç alt boyuttan oluşmaktadır. Ölçek, Likert tipi beş derecelendirmeli (1- Kesinlikle katılmıyorum, 2-Katılmıyorum, 3- Kararsızım, 4- Katlıyorum ve 5- Kesinlikle katlıyorum) bir ölçme aracı olup ölçek maddelerine verilen puanlar arttkç̧a örtük program algısı artmaktadır. Ölçek, toplam puan ve 3 alt boyut puanını vermektedir. Ölçeğin geneli için Cronbach Alpha güvenirlik katsayısı .88 olarak bulunmuştur. İ̧̧erik alt boyutu için .84 , öğrenme-öğretim süreci alt boyutu için .87 ve değerlendirme alt boyutu için .61 olarak saptanmıştrr.

Yapılan bu araştırmanın Cronbach's Alpha güvenirlik katsayısı ölçeğin toplamında .90, içerik alt boyutunda .81, öğrenme-öğretim süreci alt boyutunda .85 ve değerlendirme alt boyutunda .73 olarak bulunmuştur.

Araştırma verilerinin çözümlenmesinde, SPSS programı kullanılarak, yüzde dağılımları, t-testi, varyans ve korelasyon analizleri uygulanmış, önem düzeyi .05 olarak alınmıştır.

\section{Bulgular ve Tartışma}

Araştırma kapsamına alınan öğrenci hemşirelerin, \% 87,9’u (298) kadın, \% 62,5'i (212) 21-23 yaş grubunda, \% 73,5'i (249) Anadolu Lisesi mezunudur. Öğrenci hemşirelerin, \% 43,4'ü (147) mesleği isteyerek seçtiğini, \% 45,1'i (153) mesleğini sevdiğini ve \% 45,7'si (155) ise kısmen sevdiğini, \% 59,9'u (193) eğitim programlarından memnun olmadığını belirtmişlerdir.

Tablo 1. Örtük Program Ölçeği Puan Ortalamaları

\begin{tabular}{lcc}
\hline Ölçekler & X & Ss \\
\hline Örtük Program Ölçeği Toplamı & 50,87 & 12,07 \\
İçerik & 23,89 & 5,71 \\
Öğrenme-Öğretme süreci & 17,03 & 5,32 \\
Değerlendirme & 9,94 & 3,18 \\
\hline
\end{tabular}

Örtük Program Ölçeği değerlendirmesinde, toplam puan arttkça örtük program algısı artmaktadır (Akbulut ve Aslan 2016). Bu araştırmada öğrenci hemşirelerin ifadeleri doğrultusunda, fakülteye yönelik örtük program algısının orta düzeyde $(X=50,87 \pm 12,07)$ olduğu sonucuna ulaşılmıştir.

İlgili literatürde, her fakültenin hatta her bölümün kendine özgü örtük programlarının olabileceği vurgulanmaktadır (Sarı 2007, Ercan ve ark. 2009, Ornstein ve Hunkins 2009). Bolat'ın (2014) yapttğı sınıf içi örtük programı tanımaya yönelik nitel araştırma, Yüksel'in (2002a) yükseköğretimde yaptğı örtük program çalışması ve țp ve hemşirelik alanında yapılan (Jaye ve ark. 2005, Jafree ve ark. 2015) örtük program çalışmalarında, ortaöğretimden yükseköğretime, sağılk alanlarından, sanatsal alanlara kadar eğitimin her alanında örtük programın varlığı tespit edilmiştir. Bu doğrultuda, araştırma yapılan fakültedeki örtük program varlığının algısı literatür ve araştırmalar ile de paralellik göstermektedir.

Tablo 2. Örtük Program Ölçeği Maddelerinden En Yüksek Puan Alan illk Üç Maddenin Dağılımı

\begin{tabular}{|c|c|c|}
\hline Maddeler & $\mathrm{X}$ & Ss \\
\hline Öğretim üyeleri öğrencinin sadece kendisini dinlemesini ister. (Madde 6) & 3,03 & 1,15 \\
\hline $\begin{array}{l}\text { 2a. Ders süresince öğretim üyeleri öğrencilerin fikirlerini açıklamasına izin vermez. (Madde } \\
\text { 17) }\end{array}$ & 2,99 & 1,10 \\
\hline $\begin{array}{l}\text { 2b. Öğretim üyeleri değerlendirme yapacakları kriterleri sınav ya da ödevden önce belirtir. } \\
\text { (Madde 21) }\end{array}$ & 2,99 & 1,10 \\
\hline $\begin{array}{l}\text { Ders süresince öğretim üyeleri kendi ideolojileri ile uyumlu olmayan fikirleri eleştirir. } \\
\text { (Madde 1) }\end{array}$ & 2,78 & 2,78 \\
\hline
\end{tabular}

Tablo 2'de Örtük Program Ölçeği maddelerinden en yüksek puan alan ilk üç madde verilmiştir. Madde 17 ile madde 21 in puan ortalamaları ve standart sapmaları aynı değerde bulunmuştur $(2,99 \pm 1,10)$. Örtük program ölçeği değerlen- 
dirmesinde toplam puan arttkça örtük program algısının da arttğı belirtilmiştir (Akbulut ve Aslan 2016). Bu durumda sırasıyla 6., 17., 21. ve 1. maddelerin en yüksek puan ortalamalarına sahip olmaları maddelerde belirtilen ifadeler hakkında örtük programın daha yoğun olduğunu göstermektedir. Genel anlamda bu dört madde incelendiğinde ise öğretim elemanlarının; öğretmen odaklı dersler işlediği, öğrencilerle açık ve aktif bir iletişimde bulunulmadığı, ders değerlendirme kriterlerini açık bir şekilde ve değerlendirme yapmadan önce belirtmediği ve öğretim elemanlarının farkı fikir ve görüşlere açık olmamakla birlikte bu tür durumlara eleştirel yaklaştığı ifade edilmiştir. Eğitim; insanı insan kılma, özgürleştirme ve olgunlaştırma eylemidir. Bireyi bilişsel, duyuşsal ve psikomotor öğrenme alanlarının tümünü esas alarak dengeli bir şekilde geliştirmek zorundadır. Bu zorunluluk hem birey hem de toplum açısından gereklidir (Milli Eğitim Bakanlı̆̆ı 1973). Özellikle üniversite düzeyinde bireylerin açık görüşlü, anlayışlı, kendini ifade edebilen kendini gerçekleştirmiş bireyler olarak mezun olmaları oldukça önem taşımaktadır. Öğrencilerin ifade ettikleri bu örtük uygulamalar gerek öğretim elemanları gerekse okul yönetimi açısından önemle dikkate alınmalı ve gerekli görülen düzenleme, etkinlik ve ya farkındalık arttırmaya yönelik girişimlerle bu eksiklikler giderilmeye çalışılmalıdır.

\section{Tablo 3. Örtük Program Ölçeği Maddelerinden En Düşük Puan Alan Son Üç Maddenin Dağılımı}

\begin{tabular}{lcc}
\hline Maddeler & $X$ & Ss \\
\hline $\begin{array}{l}\text { Ders süresince öğretim üyeleri kendileri ile aynı görüşteki öğrencilere tolerans sağlayarak dersi } \\
\text { çalışmadan geçmelerini sağlar. (Madde 13) }\end{array}$ & 1,97 \\
$\begin{array}{l}\text { 2a. Ders süresince öğretim üyeleri kitapta yer alsa bile kendi fikirleri ile çelişen düşünceleri } \\
\text { görmezden gelir. (Madde5 ) }\end{array}$ & 2,00 &, 91 \\
$\begin{array}{l}\text { 2b. Ders süresince öğretim üyeleri gelir, aile ve sosyal olanaklar sebebi ile bazı öğrencilere } \\
\text { daha çok söz hakkı verir. (Madde 11) }\end{array}$ & 2,00 \\
$\begin{array}{l}\text { 3. Öğretim üyeleri gelir, aile ve sosyal olanaklar sebebi ile bazı öğrencilere daha yüksek not } \\
\text { verir. (Madde 10) }\end{array}$ & 2,01 &, 93 \\
\hline
\end{tabular}

Tablo 3'te Örtük Program Ölçeği maddelerinden en az puan alan ilk üç madde verilmiştir. Madde 5 ile madde $11^{\prime}$ in puan ortalamaları ve standart sapmaları aynı değerde bulunmuştur $(2,00 \pm, 90)$. Örtük program ölçeği değerlendirmesinde toplam puan azaldıkça örtük program algııının da azaldığı belirtilmiştir (Akbulut ve Aslan 2016). Bu durumda sırasıyla 13., 5., 11. ve 10. maddelerin en düşük puan ortalamalarına sahip olmaları maddelerde belirtilen ifadelere yönelik örtük programın daha az uygulandığını göstermektedir. Genel anlamda bu dört madde incelendiğinde ise öğretim elemanlarının; kendi görüşlerine yakın olanlara ders geçme konusunda tolerans sağlamadıkları, kendi düşüncesi ile uyuşmayan bilimsel bilgileri öğrencilere aktarmada bir sıkıntı yaşamamaları ve sosyo-ekonomik açıdan öğrenciler arasında gerek daha çok kendini ifade firsatı verme gerekse not verme durumları açısından ayrım yapmadıkları öğrenciler tarafindan ifade edilmiştir. Örtük programın olumsuz kazanımları üzerinden hazırlanan bu ölçme aracında yukarıda ifade edilen olumsuz durumların öğretim elemanları tarafindan gerek bilinçli gerekse farkında olmadan aktarılmaması eğitim verilen okul açısından oldukça olumlu bir durumdur. Nitekim eğitim; sınıfsal, cinsel, ırksal, grupsal eşitsizlikleri yeniden üreten bir durumda ise, o zaman çağdaş, demokratik bir toplumun gereksinimlerine göre müfredatların yeniden düzenlenmesi gerekir (Tezcan 2007). Ek olarak bu pozitif geri bildirimlerin gerek okul yönetimin gerekse öğretim elemanlarının haberdar olması motivasyon ve farkındalık açısından olumlu sonuçlar doğuracağı düşünülmektedir.

Tablo 4. Öğrenci Hemşirelerin Sınıfları İle Örtük Program Ölçeğinin Karşılaştırılması

\begin{tabular}{lccccccccccccc}
\hline & \multicolumn{2}{c}{ 1. Sınıf } & \multicolumn{2}{c}{ 2. Sınıf } & \multicolumn{2}{c}{ 3. Sınıf } & \multicolumn{3}{c}{ 4. sınıf } \\
Örtük Program Ölçeği & X & Ss & X & Ss & X & Ss & X & Ss & $F$ & $\mathrm{p}$ \\
\hline Ölçek Toplamı & 47,61 & 11,87 & 48,40 & 11,09 & 49,89 & 11,94 & 57,03 & 11,20 & 10,987 &, 000 \\
İçerik & 22,32 & 5,79 & 22,33 & 5,13 & 24,82 & 6,00 & 25,19 & 5,16 & 6,192 &, 000 \\
Öğrenme-Öğretme Süreci & 15,88 & 5,35 & 16,61 & 4,78 & 15,82 & 4,71 & 20,06 & 5,48 & 13,494 &, 000 \\
Değerlendirme & 9,40 & 3,12 & 9,45 & 2,76 & 9,25 & 3,26 & 11,78 & 2,77 & 13,597 &, 000 \\
\hline
\end{tabular}

Tablo 4'de öğrenci hemşirelerin sınıfları ile örtük program ölçeğinin karşılaştııılmasına yönelik bulgular yer almaktadır. Tablo 4 incelendiğinde; örtük program ölçeğinin toplamı ve alt boyutları ile sınıf değişkeni arasında ileri derecede anlamlı bir fark bulunmuştur $(p<0,05)$. Birinci sınıftan dördüncü sınıfa doğru öğrenci hemşirelerin sınıfları büyüdükçe örtük program algılarının da arttı̆ı görülmüştür. Yapılan çalışmalarda ve ilgili literatürde öğrencilerin eğitim kurumlarını 
ve kurumun kültürlerini tanıma düzeyinin ve öğrenci olgunluğu arttkça fakülteye ait örtük program algısının arttğı belirtilmektedir (Senemoğlu, 2013; Ercan ve ark. 2009; Akbulut ve aslan, 2016).

Sonuç olarak, dört yıllık eğitim programını çoğunu tamamlama ve tanıma firsat bulan hemşirelik son sınıf öğrencilerinin, kurumun eğitim programını ve örtük programını daha iyi değerlendirebildiği ve bununda ilgili literatür ve çalışmalar ile paralellik gösterdiği görülmektedir. Ayrıca bu sonuca göre, araştırma yapılan fakültede öğrencilerin eleştirel düşünme yetilerinin geliştiği, farkındalık düzeylerini arttırdığı ve daha bilinçli bireyler yetiştirdiği söylenebilir.

Tablo 5. Öğrenci Hemşirelerin Sosyo-Demografik Özellikleri ile Örtük Program Ölçeğinin Karşılaştırılması

\begin{tabular}{|c|c|c|c|c|c|c|c|c|}
\hline \multicolumn{9}{|c|}{ Örtük Program Ölçeği (ÖPÖ) } \\
\hline & \multicolumn{2}{|c|}{ Ölçek Toplamı } & \multicolumn{2}{|c|}{ İçerik } & \multicolumn{2}{|c|}{$\begin{array}{c}\text { Öğrenme-Öğretme } \\
\text { Süreci }\end{array}$} & \multicolumn{2}{|c|}{ Değerlendirme } \\
\hline & $x$ & Ss & $x$ & Ss & $x$ & Ss & $x$ & Ss \\
\hline \multicolumn{9}{|l|}{ Cinsiyet } \\
\hline Kadın (298) & 50,11 & 11,78 & 23,62 & 5,73 & 16,70 & 5,11 & 9,78 & 3,18 \\
\hline Erkek (41) & $\begin{array}{c}56,46 \\
t=3,203\end{array}$ & $\begin{array}{c}12,88 \\
p=, 001\end{array}$ & $\begin{array}{c}25,85 \\
t=2,361\end{array}$ & $\begin{array}{c}5,27 \\
p=, 019\end{array}$ & $\begin{array}{c}19,48 \\
t=3,182\end{array}$ & $\begin{array}{c}6,20 \\
p=, 002\end{array}$ & $\begin{array}{c}11,12 \\
t=2,538\end{array}$ & $\begin{array}{c}2,95 \\
p=, 012\end{array}$ \\
\hline \multicolumn{9}{|l|}{ Yaş Grupları } \\
\hline 18-20 Yaş (110) & 49,00 & 11,37 & 23,15 & 5,58 & 16,43 & 5,02 & 9,02 & 3,07 \\
\hline 21-23 Yaş (212) & 50,83 & 12,06 & 24,01 & 5,78 & 16,80 & 5,23 & 10,01 & 2,18 \\
\hline 24 ve Üzeri Yaş (17) & $\begin{array}{c}63,47 \\
F=11,197\end{array}$ & $\begin{array}{c}9,40 \\
p=, 000\end{array}$ & $\begin{array}{c}27,05 \\
F=3,633\end{array}$ & $\begin{array}{c}4,65 \\
p=, 027\end{array}$ & $\begin{array}{c}23,82 \\
F=15,992\end{array}$ & $\begin{array}{c}3,72 \\
p=, 000\end{array}$ & $\begin{array}{c}10,71 \\
F=11,197\end{array}$ & $\begin{array}{c}2,64 \\
p=, 000\end{array}$ \\
\hline \multicolumn{9}{|l|}{ Meslek Sevgisi } \\
\hline Evet (153) & 49,07 & 12,07 & 22,86 & 5,53 & 16,79 & 5,39 & 9,41 & 3,22 \\
\hline Kısmen (155) & 51,71 & 10,80 & 24,48 & 4,97 & 16,87 & 4,97 & 10,36 & 3,08 \\
\hline \multirow{2}{*}{ Hayır (31) } & 55,58 & 16,20 & 25,96 & 6,37 & 19,09 & 6,37 & 10,51 & 3,16 \\
\hline & $F=5,527$ & $p=, 011$ & $F=5,466$ & $p=, 005$ & $F=2,579$ & $p=, 077$ & $F=4,033$ & $p=, 019$ \\
\hline
\end{tabular}

Öğrenci hemşirelerin sosyo-demografik özellikleri ile örtük program ölçeğinin karşılaştrılması sonucu elde edilen bulgular Tablo 5'te verilmiştir. Tablo 5 incelendiğinde; örtük program ölçeğinin toplamı ve alt boyutları ile cinsiyet, yaş grupları ve meslek sevgisi arasında ileri derecede anlamlı bir fark bulunmuştur $(p<0,05)$. Fakülteye yönelik örtük program algısı puan ortalamaları incelendiğinde; erkek öğrencilerin ve yaş grubu yüksek olan öğrencilerin örtük program algılarının daha yüksek olduğu sonucuna ulaşılmıştı. Aynı zamanda meslek sevgisi azaldıkça örtük program algısının arttı̆ı da görülmektedir.

Erkek öğrencilerin örtük program algııının daha yüksek olması, mesleklerin temelde erkek ve kadın mesleği olarak ayrılmış olmasına dayandırılmaktadır. Hemşirelik mesleğinde her geçen gün sayılarının artmasına rağmen erkek öğrenciler, gerek eğitim kurumlarında gerekse uygulama ve çalışma alanlarında cinsiyet ayrımı yaşadıklarını ifade etmişlerdir (Tezcan 2007; Kahraman, Tunçdemir ve Özcan 2015; Aydın, Bekar ve Gören 2016). Cinsiyet ve mesleki ayrımların örtük programı ölçmek için kullanılan ifadelerde yer aldığı bilinmektedir (Tezcan 2007, Ercan ve ark. 2009, Akbulut ve Aslan 2016). Bu sebeplerin erkek hemşirelik öğrencilerinin örtük program algısını güçlendirdiği düşünülmektedir. Ayrıca ulaşılan sonuca göre erkek öğrencilerin eleştirel düşünme yetilerinin ve farkındalık düzeylerinin kadın öğrencilerden yüksek olduğu da söylenebilir.

Yaş gruplarına yönelik sonuçlara bakıldığında, yaş grubu yüksek olan öğrencilerin örtük program algılarının daha yüksek olduğu saptanmıştı. Yapılan araştırmalar, örtük program hakkında yorum yapabilmek için o kurumu, işleyişini, çalışanları tanımış olmak gerektiğini göstermekte ve yaşın artması ile beraber öğrencilerin farkındalık düzeylerinin ve olgunluklarının da arttğı bilinmektedir (Senemoğlu 2013, Ercan ve ark. 2009, Akbulut ve Aslan 2016). Nitekim ilköğretim düzeyi ya da yükseköğretim düzeyinde örtük program ile ilgili yapılan çalışmaların çoğunluğunda son sınıf öğrencilerinin tercih edildiği görülmektedir (Ercan ve ark. 2009, Bolat 2014, Alimoğlu ve ark. 2013; Murakami, Kawabata ve Maezawa 2009, Karimi ve ark. 2014 ). Bu doğrultuda araştırmadan elde edilen bulgunun beklenen bir sonuç olduğu ve 
diğer araştrrma bulguları ile benzerlik gösterdiği görülmüştür.

Hemşirelik mesleğini sevme oranı azaldıkça öğrencilerin örtük program algılarının arttğı görülmüştür (Tablo 5). Yapılan çalışmalarda, okula yönelik olumsuz tutumların öğrencilerin okulla ilgili tüm algılarını etkilediği belirtilmektedir (Tezcan 2007, İnal 2007). Bu bağlamda mesleğini sevmeyen bir öğrencinin meslek edindiği eğitim kurumunu ve eğitim ortamını da sevmediği düşünülmektedir. Nitekim araştırma için kullanılan ölçek maddeleri de eğitim kurumunun örtük program açısında olumsuz çıktılarını ele alarak değerlendirmiştir. Dolayısıyla mesleği hakkında olumsuz tutum içindeki bir öğrencinin eğitim kurumu ile ilgili tüm algılarının da olumsuz olması beklenen bir sonuçtur.

Tablo 6. Öğrenci Hemşirelerin Memnuniyet Durumları İle Örtük Program Ölçeğinin Karşılaştırılması

$$
\text { Örtük Program Ölçeği (ÖPÖ) }
$$

\begin{tabular}{|c|c|c|c|c|c|c|c|c|}
\hline \multirow{2}{*}{$\begin{array}{l}\text { Memnuniyet } \\
\text { Eğitim programından }\end{array}$} & \multicolumn{2}{|c|}{ Ölçek Toplamı } & \multicolumn{2}{|c|}{ İçerik } & \multicolumn{2}{|c|}{ Öğrenme-Öğretme Süreci } & \multicolumn{2}{|c|}{ Değerlendirme } \\
\hline & $x$ & Ss & $x$ & Ss & $x$ & Ss & $x$ & Ss \\
\hline Evet (49) & 48,48 & 12,25 & 22,18 & 5,58 & 16,93 & 5,29 & 9,61 & 3,06 \\
\hline \multirow{2}{*}{ Kısmen (193) } & 50,07 & 11,09 & 23,34 & 5,09 & 17,42 & 5,08 & 9,79 & 2,99 \\
\hline & 53,68 & 13,14 & 25,82 & 6,48 & 17,03 & 5,82 & 10,42 & 3,57 \\
\hline Hayır (97) & $F=4,071$ & $\mathrm{p}=.018$ & $F=9,086$ & $p=.000$ & $\mathrm{~F}=, 391$ & $\mathrm{p}=.676$ & $F=1,582$ & $p=.207$ \\
\hline \multicolumn{9}{|l|}{ Okul yönetiminden } \\
\hline \multirow{2}{*}{ Evet (101) } & 47,84 & 12,16 & 22,23 & 5,50 & 16,32 & 5,56 & 6,27 & 3,02 \\
\hline & 51,32 & 11,31 & 24,07 & 5,40 & 17,18 & 4,95 & 10,07 & 3,09 \\
\hline Kısmen (194) & 55,84 & 13,43 & 26,88 & 6,26 & 18,02 & 6,22 & 10,93 & 3,68 \\
\hline Hayır (44) & $F=7,306$ & $p=.001$ & $F=10,978$ & $p=.000$ & $F=1,733$ & $\mathrm{p}=.178$ & $F=4,576$ & $p=.011$ \\
\hline \multicolumn{9}{|l|}{ Öğr. elemanlarından } \\
\hline \multirow{2}{*}{ Evet (114) } & 48,45 & 1,79 & 22,52 & 5,32 & 16,59 & 5,48 & 10,05 & 2,80 \\
\hline & 50,97 & 11,03 & 23,92 & 5,27 & 16,98 & 5,04 & 11,30 & 3,16 \\
\hline Kısmen (189) & 58,02 & 15,28 & 28,02 & 7,12 & 18,69 & 6,08 & 9,94 & 3,94 \\
\hline Hayır (36) & $F=9,015$ & $\mathrm{p}=, 000$ & $F=13,631$ & $\mathrm{p}=.000$ & $F=2,154$ & $\mathrm{p}=.118$ & $F=5,651$ & $p=.004$ \\
\hline \multicolumn{9}{|l|}{ İdari çalışanlardan } \\
\hline \multirow{2}{*}{ Evet (84) } & 47,69 & 12,27 & 21,97 & 5,57 & 16,30 & 5,74 & 16,30 & 5,74 \\
\hline & 51,31 & 11,32 & 23,81 & 5,09 & 17,51 & 5,02 & 17,51 & 5,02 \\
\hline Kısmen (191) & 53,73 & 13,20 & 26,64 & 6,58 & 16,56 & 5,56 & 16,56 & 5,56 \\
\hline Hayır (64) & $F=4,957$ & $\mathrm{p}=, 008$ & $F=13,001$ & $\mathrm{p}=.000$ & $\mathrm{~F}=1,825$ & $\mathrm{p}=.163$ & $F=2,326$ & $p=.099$ \\
\hline \multicolumn{9}{|l|}{ Klinik hemşirelerden } \\
\hline \multirow{2}{*}{ Evet (77) } & 48,79 & 11,57 & 22,32 & 5,38 & 17,11 & 5,30 & 9,35 & 2,67 \\
\hline & 50,32 & 11,39 & 23,82 & 5,32 & 16,61 & 5,24 & 9,88 & 3,15 \\
\hline Kısmen (229) & 59,57 & 14,40 & 28,00 & 7,11 & 19,78 & 5,31 & 11,78 & 3,86 \\
\hline Hayır (33) & $F=10,508$ & $p=, 000$ & $F=12,192$ & $p=, 000$ & $F=5,252$ & $p=, 006$ & $F=7,152$ & $p=, 001$ \\
\hline
\end{tabular}

Eğitim programından, okul yönetiminden, öğretim elemanlarından, idari çalışanlardan ve klinik hemşirelerinden memnuniyet durumları ile örtük program ölçeği toplam puanı arasında ileri derecede anlamlı bir fark bulunmuş $(p<0,05)$, öğrencilerin bu faktörlerden memnuniyet düzeyleri azaldıkça örtük program algısının arttğı sonucuna ulaşılmıştır.

Örtük program, öğrencilerin günlük ve eğitsel rutinler içinde öğrendikleri, özümsedikleri anlam, inanç ve doğruları ifade etmektedir (İnal 2007, Yüksel 2002, Bacanlı 2006). Roland (1991); mesleği sevmeme, okul ortamından uzaklaşma, 
karamsarlık gibi durumların örtük programa yönelik tepkiler olabileceğini vurgulamaktadır (Akt. İnal 2007). Kullanılan ölçme aracının da örtük programın olumsuz sonuçlarını ele aldığını düşündüğümüzde öğrencilerin memnun olmadığı durumları daha eleştirel bir bakış açısı ile inceledikleri ve okula yönelik örtük program algılarını arttı̆ı sonucuna ulaşmamız beklenen bir sonuçtur.

\section{Sonuç ve Öneriler}

Öğrenci hemşirelerin, eğitim gördükleri kuruma yönelik örtük program algılarını belirlemek amacıyla yapılan bu çalışmada; fakülteye yönelik örtük program algısının orta düzeyde olduğu, erkek olmanın, mesleği tesadüfen seçmenin, 24 ve üzeri yaşta olmanın, mesleği sevmemenin ve eğitim programından, okul yönetiminden, öğretim elemanlarından, idari çalışanlardan ve klinik hemşirelerden memnuniyetin azalmasının örtük program algısını artth̆̆ı sonucuna ulaşılmıştr.

Araştırma sonuçlarına bakıldığında meslek sevgisinden memnuniyet durumlarına kadar daha birçok konuda öğrencileri etkilediği bilinen örtük program, genel hedefi değerler sistemi gelişmiş çağdaş insan profiline ulaşmak ve yaşam boyu öğrenmeyi benimseyerek profesyonel hemşireler yetiştirmek" olan yükseköğretimde hemşirelik eğitimin değerlerin kazanılması sürecinde bir avantaj, teşvik ve yönlendirme aracı olarak görmeli ve resmi programda olduğu gibi planlı etkinlikler haline getirmelidir.

Ölçek maddeleri incelenerek hangi konularda örtük program algısının daha fazla olduğu sonucu okul yönetimi ve çalışanları ile paylaşılarak o yönde gerekli önlemler alınabilir ve ya gereken yenilikler için fikir oluşturulabilir. En az resmi program kadar etkili olduğu bilinen ve hemşirelik eğitimi için de oldukça önemli olan bu konunun yapılacak başka çalışmalarla desteklenmesi ve planlanması önerilmektedir.

Her kurumun hatta her bölümün kendine özgü bir örtük programı olduğu bilindiği için hemşirelik bölümü kendisi için uygun olan bir örtük program ölçeği geliştirerek kurumunu ve hem formal hem örtük programını daha iyi tanıma firsatı bulabilir. Gizli müfredat, bireylerin farklı gereksinmeleri ve yaratıcı yönlerini ortaya çıkaracak biçimde tasarımlandığında, formal eğitim programlarıyla bütünleşmesi sağlanabilir.

\section{Kaynakça}

Akbulut, N., Aslan, S. (2016).Örtük Program Ölçeği: Ölçek Geliştirme Çalışması. Elektronik Sosyal Bilimler Dergisi, 15(56), 169-176.

Aksu B. M., Çivitçi A., Duy B. (2008).Yükseköğretim Öğrencilerinin Öğretim Elemanlarının Ders Uygulamaları ve Sınıf İçi Davranışlarına Illişkin Görüşleri. İnönü Üniversitesi Eğitim Fakültesi Dergisi, 9(16), 17-42.

Allan H. T., Smith P., O'Driscoll M. (2011). Experiences Of Super Numerary Statusand The Hidden Curriculum In Nursing: A Newtwist In Thetheory-Practicegap? Journal Of Clinical Nursing, 20, 847-855.

Bacanlı, H. (2006). Duyuşsal davranış eğitimi. 3. Baskı. Ankara: Nobel Yayın Dağıım.

Başar M., Akan D., Çankaya i. E. (2014). Örtük Program Çerçevesinde Okul Yöneticilerinin Yönetsel Uygulamalarının Değerlendirilmesi. Erzincan Üniversitesi Eğitim Fakültesi Dergisi, 16(1), 239-263.

Bolat, Y. (2014). Öğrenci Gözüyle Sınıfin Örtük Programı. Adıyaman Üniversitesi Sosyal Bilimler Enstitüsü Dergisi, 7(18).

Brammer, J. D. (2006). RN as Gatekeeper: Student Understanding Of The RN Buddy Role İn Clinical Practice Experience. Nurse EducationToday, 26, 697-704.

Demirel, Ö. (2015). Eğitimde Program Geliştirme kuramdan uygulamaya. Ankara: Pegem A Yayıncılık.

Ercan I., Yüksel S., Özkaya G., Ocakoğlu G., Yükse A., Uncu, Y. (2009). Tıp Fakültesi Örtük Program Ölçeninin Geliştirilmesi. Cerrahpaşa Tıp Dergisi, 40(3), 81-87.

Flinders, D. J. ve Thornton. S. J. (2004). The Curriculum Studies Reader. New York: Routledge.

Hemşirelik Eğitimi Derneği. (2014). Hemşirelik Ulusal Çekirdek Eğitim Programı (HUÇEP) $2<$ <ttp://www.hemed.org.tr/images/ stories/hucep-2014-pdf.pdf > (2016, Kasım 03)

Jafree S. R., Zakar R., Fischer F., Zakar M. Z. (2015). Ethical Violations in The Clinical Setting: The Hidden Curriculum Learning Experience Of Pakistani Nurses. Medical Ethics,16(16).

Jaye C., Egan T., Parker, S. (2005). Learning to be a doctor: MedicalEducators Talk About The Hidden Curriculum in MedicalEducation. Focus On Health Professional Education: A Multi-Disciplinaryjournal, 7, 1-11.

Johnson J. G., Hellıwell J., Nicholson J., Reay D., Schwarz H., Wright, G. (1989). “The Infant Years” Educationand Equality. (Ed. M. Cole) London: Routledge,

Milli Eğitim Bakanlığı (1973). <http://dhgm.meb.gov.tr/yayimlar/dergiler/Milli_Egitim_Dergisi/147/fer.htm> (2017, Ocak 10)

Murat M., Özgan H., Aslantaş H. (2005). Öğretmen Adaylarının Öğretim Elemanlarının Empatik Tutumlarına iliş̧kin Algıları Ile Ders Başarıları Arasındaki Illişki. <http://yayim.meb.gov.tr/dergiler/168/index3-arslantas.htm > (2016, Ekim 31) 
Ornstein, C. A. ve Hunkins, P. F. (2009).Curriculum Foundation, Principles, Andlssues. USA: Pearson.

Senemoğlu, N. (2013). Gelişim Öğrenme Ve Öğretim. Ankara: Yargı Yayınları.

Senemoğlu, N. (2013). Gelişim, Öğrenme ve Öğretim Kuramdan Uygulamaya (23. Baskı). Ankara: Yargı Yayınevi.

Skelton, A. (1997). Studying Hidden Curricula: Developing A Perspective İn TheLight Of Post Modern İn Sights, Curriculumstudies, $5(2), 177-193$

Sönmez, V. (2012). Program Geliştirmede Öğretmen El Kitabı. Ankara: Anı Yayıncılık.

Takala M., Hawk D.,Yannis R. (2001). “On theOpening of Society: Towards a More Open andFlexibleEducationalSystem”, SystemsResearchandBehavioralScience, Special issue on DesigningEducationalSystemsfortheTwenty-First Century, 18 (4), $291-306$.

Tresolini, C. (1994). Health professions education and relationship centered care: Report of thepew-fetzertask force on advancing psychosocial education. San Francisco: Pew Health Professions Commission.

Wilkinson, T. J. (2016). Stereotypes And The Hidden Curriculum Of Students. Medıcal Education, 50, 798-806.

Yalçınkaya, M. (2002). Öğrencilerin Öğretim Elemanlarını Değerlendirmesi Araştırması: Gazi Üniversitesi Ticaret Ve Turizm Eğitim Fakültesi Örneği. <http://gazi.edu.tr/posts/download?id=152317 > (2016, Ekim 30).

Yüksel, S.(2002b). Örtük Program. Eğitim ve Bilim, 27(126), 31-37.

Yüksel, S. (2002a). Yükseköğretimde Eğitim-Öğretim Faaliyetleri ve Örtük Program. Uludağ Üniversitesi Eğitim Fakültesi Dergisi, 15(1).

Sarı M. (2007). Demokratik Değerlerin Kazanımı Sürecinde Örtük Program: Düşük ve Yüksek “Okul Yaşam Kalitesi”Ne Sahip íki ilköğretim Okulunda Nitel Bir Çalışma. Yayımlanmamış Doktora Tezi. Çukurova Üniversitesi, Adana.

Tezcan, M. (2007). Gizli Müfredat Eğitim Sosyolojisi Açısından Bir Kavram Çözümlemesi. Türk Eğitim Bilimleri Dergisi, 1(1).

Kahraman A. B, Ozansoy Tunçdemir N., Özcan A. (2015). Toplumsal Cinsiyet Bağlamında Hemşirelik Bölümünde Öğrenim Gören Erkek Öğrencilerin Mesleğe Yönelik Algıları. Sosyoloji Araştırmaları Dergisi. 18(2), 108-144

Aydın M., Özen Bekar E., Yılmaz Gören Ş., Sungur M. A. (2016). Hemşirelik Öğrencilerinin Toplumsal Cinsiyet Rollerine i̇lişkin Tutumları. АїB̈̈ Sosyal Bilimler Enstitüsü Dergisi, 16(1), 223-242.

Akbulut E. (2011). İlköğretim Okullarında Örtük Program Faaliyetlerinin Saptanması. Yayımlanmamış Yüksek Tezi İnönü Üniversitesi, Malatya.

Murakami M., Kawabata H., And Maezawa M. (2009). The Perception Of The Hidden Curriculum On Medical Education: An Exploratory Study. Asia Pacific Family Medicine, 8(9). 